\title{
Mass change study on Arctic glacier Pedersenbreen, during 1936-1990-2009
}

\author{
AI SongTao ${ }^{1 *}$, WANG ZeMin ${ }^{1}$, TAN Zhi ${ }^{1}$, E DongChen $^{1} \&$ YAN Ming ${ }^{2}$ \\ ${ }^{1}$ Chinese Antarctic Center of Surveying \& Mapping, Wuhan University, Wuhan 430079, China; \\ ${ }^{2}$ Polar Research Institute of China, Shanghai 200136, China
}

Received November 30, 2012; accepted January 30, 2013; published online April 17, 2013

\begin{abstract}
Pedersenbreen is a small polythermal valley glacier, located in Svalbard, which has been one of the two glaciers monitored by Chinese Arctic expedition members since 2004. This study estimates its area and volume and analyzes its change during 19361990-2009, using field collected GPS/GPR data in 2009 and historical topographic maps published by the Norwegian Polar Institute. We have found that Pedersenbreen is just like many other valley glaciers in Svalbard, having experienced a significant recession since the end of Little Ice Age in the early 20th century. The glacier tongue has retreated more than $0.6 \mathrm{~km}$, while ice volume has decreased by approximately $13 \%$. The overall thinning rate of Pedersenbreen has shown acceleration during the recent decades. Further analysis shows that the ice tongue in the downstream area of Pedersenbreen is melting at the highest rate, while a simultaneous accumulation occurred in the upstream. However, as global temperatures increase, the accumulation area is reducing year by year.
\end{abstract}

Arctic, Pedersenbreen, mass change, Digital Elevation Model

Citation: $\quad$ Ai S T, Wang Z M, Tan Z, et al. Mass change study on Arctic glacier Pedersenbreen, during 1936-1990-2009. Chin Sci Bull, 2013, 58: 3148-3154, doi: $10.1007 / \mathrm{s} 11434-013-5772-8$

Pedersenbreen $\left(78.86^{\circ} \mathrm{N}, 12.29^{\circ} \mathrm{E}\right)$, a typical small polythermal valley glacier [1], is located in Svalbard near the Ny-Ålesund community (Figure 1). The highest elevation near the glacier is $1021 \mathrm{~m}$ [2]. It is located southeast of the Chinese Yellow River Station, $10 \mathrm{~km}$ away. Pedersenbreen was one of the four key glaciers studied during the first Chinese Arctic research expedition in 2004, when Yellow River Station was set up. After that, it was chosen as a longterm monitoring glacier, as well as Austre Lovénbreen [3]. In 2005, Chinese glaciologists drilled $2 \mathrm{~m}$ boreholes and placed five observation stakes on Pedersenbreen. From then on, high precision GPS measurements have been carried out on Pedersenbreen every summer. Consequently, we have focused on glacier mass balance, surface velocities and terminal variations [4-6]. In 2009, we collected high density GPS and GPR data on the surface of Pedersenbreen, to study glacier topography, ice thickness, area and internal structure [7].

*Corresponding author (email: ast@ whu.edu.cn)
Chinese researchers have mainly studied glacier changes in Chinese territory [8], such as the Tianshan glaciers [9,10], in contrast, glaciers in Svalbard are poorly studied by Chinese. However, many foreign researchers have extensively studied glaciers in Svalbard. They reported that many glaciers have experienced a significant retreat since the end of the Little Ice Age (LIA) including thinning of ablation zones and retreating of ice tongues, and a simultaneous thickening at the uppermost parts of glaciers [11-14]. In the past few decades, the multi-source data analysis showed that Svalbard glaciers had accelerated melting trends, especially on the western side of Svalbard [15]. Currently, a series of studies, including glacial meteorological, hydrological, mass balance, retreat, ice core and culture [1], have been made on Pedersenbreen's neighbouring glaciers, such as Austre Brøggerbreen, Midtre lovénbreen, Kongsvegen, Kronebreen. A systematic study on Pedersenbreen has not been conducted. Hagen et al. [16] gave the parameters of length, area, volume, altitude range for Pedersenbreen in 


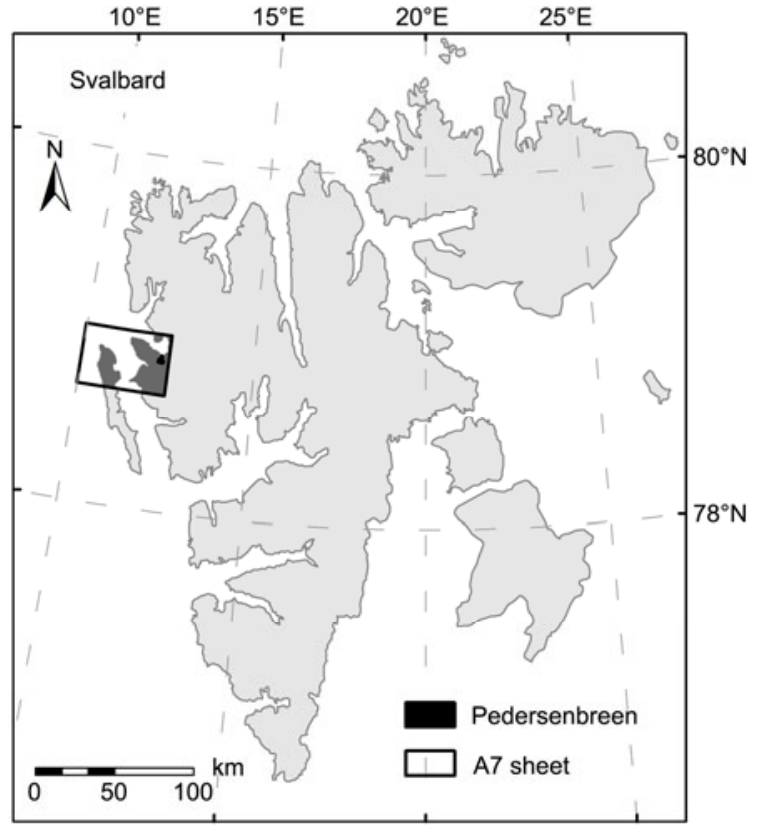

Figure 1 A map showing the location of Pedersenbreen and A7 sheet in Svalbard.

1977, in which the volume is calculated from an empirical formula. Some others found underground runoff and ponding, indicating that Pedersenbreen is a polythermal glacier [17]. Bennett et al. [18] had conducted a research on its moraine development, finding complex moraine mounds in its tongue area. There are obvious overthrusts and fold structures on terminal moraine embankments. He also found some flowing fractured zones in the surface of the glacier, and ring-like moraines in the western edge of the glaciers. For these reasons, he suggested Pedersenbreen might have surged in the past, but is currently in a quiet period.

Pedersenbreen has experienced significant retreat since the end of the Little Ice Age (LIA). This retreat is clearly manifested by the complex moraine heaps and several eskers present in front of the glacier [18]. The topographic map of the glacier also reflects its retreating trend [2]. This study mainly analyzed the change in area, volume and ice thickness of Pedersenbreen at 1936, 1990 and 2009. We used single point GPS data and GPR data collected in the field in 2009, contour lines in 1936 [19] and in 1990 [2] from historical maps published by the Norwegian Polar Institute to reconstruct digital elevation models (DEM) [20] of Pedersenbreen.

\section{Data and methods}

\subsection{Data sources}

The data of this study includes historical maps' contour lines, GPS data and GPR data. Historical maps are the A7 sheet (Kongsfjorden, Spitsbergen) of Svalbard topographic maps at 1:100000 scale published by the Norwegian Polar Institute in 1990 and 2008. These maps include ice surface contour lines in 1936 and 1990 generated by aerial photogrammetry. The common interval of contours is 50 and $25 \mathrm{~m}$ when altitude is below $50 \mathrm{~m} \mathrm{[2,19].} \mathrm{In} \mathrm{order} \mathrm{to} \mathrm{estimate} \mathrm{the}$ area, the length of central flowlines and acquire the surface DEM, we digitized the border of Pedersenbreen (Figure 2(a)) and the surface contours; we also converted data into the same geographic coordinate system (WGS84) and the same map projection (northern polar stereographic projection). The accuracy of the NPI map in 1936 is not as high due to poor aerial photo resolution and photogrammetry technology in early years. We confirmed that the error of this map is less than $\pm 15 \mathrm{~m}$ in horizontal and $\pm 7 \mathrm{~m}$ in elevation, by consulting with staff from the Norwegian Polar Institute. We compared locations and elevations of peaks surrounding Pedersenbreen between the latest data published by NPI and the data from the 1936 map, and found that the error is about $\pm 13 \mathrm{~m}$ in horizontal and $\pm 3.64 \mathrm{~m}$ in elevation. That is to say, the correlation errors have been controlled within the original accuracy (Table 1). Compared with the 1936 map, the accuracy of the topographic map in 1990 (WGS84, UTM projection) is much higher, whose error is less than $\pm 5 \mathrm{~m}$ in horizontal.

GPS data and GPR data were collected from field measurements at Pedersenbreen by Chinese expedition members. During April 2009, high density GPS and GPR points were collected on the surface of Pedersenbreen within a two week period, using two pure wooden sledges dragged slowly by a snow scooter. Total 12 survey lines, more than 14000 points, were acquired covering an area of $4.47 \mathrm{~km}^{2}$. Apart from the glacier tongue (area A, Figure 2), the northwestern tributary (area B, Figure 2), and the uphill parts located in the high elevation border area (area C, Figure 2), most areas of the glacier has been surveyed as in Figure 2. The GPS used was a NOVATEL SMART-V1, an integrated single frequency GPS. The GPR used was of the type pulseEKKO PRO, produced by Sensors \& Software Inc. in Canada. $100 \mathrm{MHz}$ antennas were chosen to conduct the survey on Pedersenbreen. The accuracy of point positioning data measured by the single frequency GPS is poor for multiple reasons. For example, the surveying area was not covered by differential GPS signal, or ionospheric and tropospheric environment were different during the surveying periods. The root mean square error of the elevation of crossing points is $2.6 \mathrm{~m}$. We developed a program named "GPRead" based on Visual C++ 6.0 to adjust and smooth the elevation data. Processed elevation data can be compared with high precision

Table 1 Correlation error of A7 sheet of the 1936 and 1990 topographic map (m)

\begin{tabular}{lccccc}
\hline & \multicolumn{2}{c}{1936} & & \multicolumn{2}{c}{1990} \\
\cline { 2 - 3 } \cline { 5 - 6 } & Mean error & Standard error & & Mean error & Standard error \\
\hline Longitude & 13.75 & 7.33 & & 4.13 & 2.91 \\
Latitude & 12.56 & 10.42 & & 4.75 & 3.29 \\
Elevation & 3.64 & 2.25 & & - & - \\
\hline
\end{tabular}



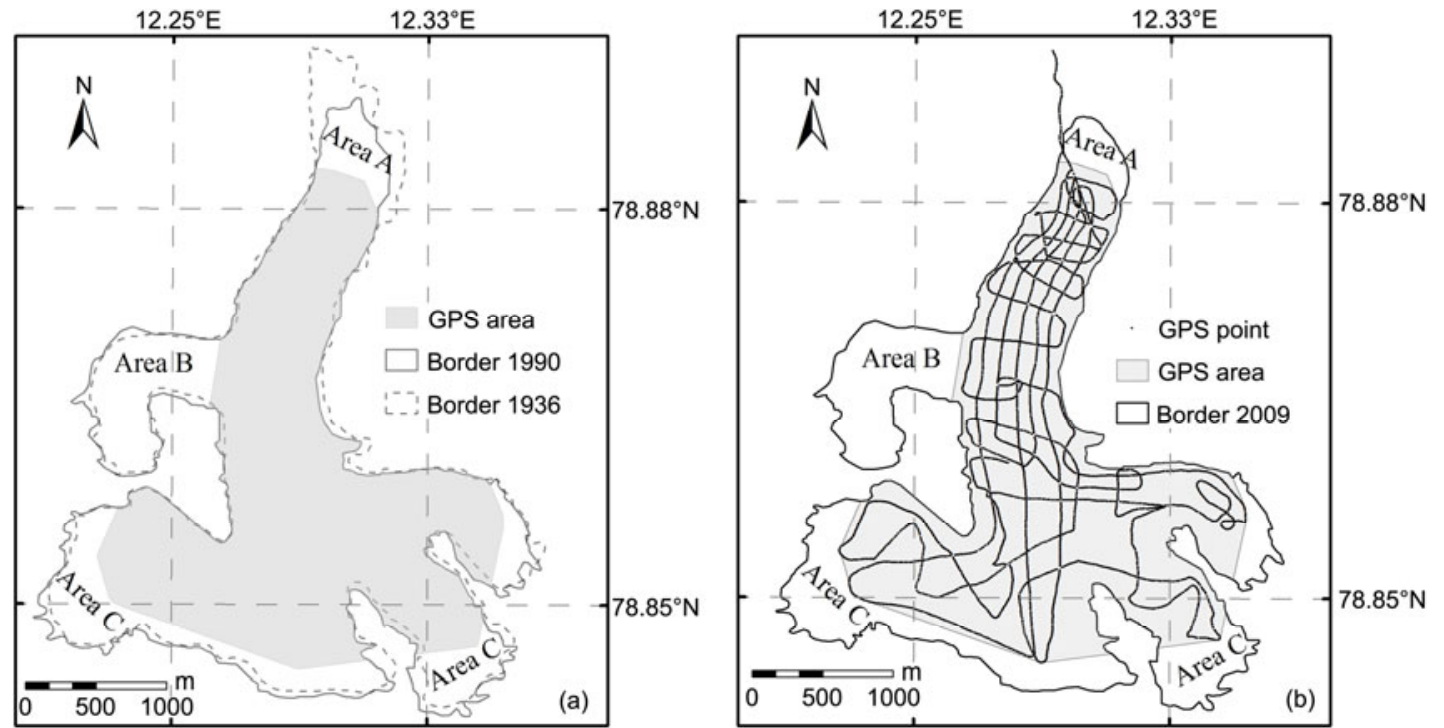

Figure 2 (a) Extent of Pedersenbreen in 1936 and 1990; (b) extent of Pedersenbreen in 2009 and GPS/GPR surveying points on glacier.

elevation acquired by dual frequency GPS at the same period. Their differences are within $\pm 1 \mathrm{~m}$, which is less than seasonal variations in the altitude and the year-around melting, so we think the resulting precision is sufficient for our glacier research works [7]. Each of the GPS points was coupled with a trace of radio sounding data measured by the GPR. The GPR section data are preprocessed with EKKO_ View Deluxe software. Using a DEWOW filter to remove unwanted low frequency "wow", and applying a SEC gain to amplify the subglacial signals, the radio echo signals show clearly in the GPR data sections. Finally the ice thickness at each point was picked out through the GPRead software (using a mean radio wave velocity of $0.16 \mathrm{~m} / \mathrm{s}$ ). From the crossing points between different profiles, we found that most thickness difference values lie in a Gaussian distribution with RMSE about $4.6 \mathrm{~m}$.

When in a recession period, valley glaciers retreat mainly in tongue area, however a change of glacier borders at higher altitude is not always obvious [21]. We also found that the retreat of Pedersenbreen mainly concentrates in the glacial tongue, the change of border in the accumulation area is very small between 1936 and 1990 as in Figure 2(a). Unfortunately, accurate glacier edge data was not able to be collected through field GPS measurement because it is inaccessible due to the steep slopes. There were only a few terminal points collected at the glacial tongue in area $\mathrm{A}$, while the edge points in areas B and $\mathrm{C}$ were not acquired. Considering the time span between 1990 and 2009 is much shorter, we used the edge of the accumulation zone in 1990 as well as the edge in 2009 (Figure 2(b)).

\subsection{Estimation of ice-volume for Pedersenbreen in three years}

Using the elevation data of the glacial surface from GPS measurements minus the ice thickness acquired from GPR, the elevation at ice-bedrock interface of each point is obtained. From all the ice-bedrock interface points we can establish the DEM of bedrock topography for Pedersenbreen. The glacier movement may produce erosion on the glacier bedrock, which will change the subglacial topography [21], while the process is slow. Seddick and some other researchers thought that when the basal sliding rate is at 6-7 m/a, the change from $\mathrm{V}$-shaped into $\mathrm{U}$-shaped valley of the glacier needs $50 \mathrm{ka}$ [22]. Harbor inferred that the maximum cross-sectionally averaged erosion rate is $5 \mathrm{~mm} / \mathrm{a}$ from a simulation [23]. Usually the subglacial topography is considered not to have changed much in 100 years, and the influence of bedrock changing upon the glacier volume estimation can be ignored [24]. Because this study involves a time span of 73 years, we use the subglacial topography obtained in 2009 for 1936 and 1990. The glacier volume can be calculated by subtracting the bedrock DEM from the surface DEM. The surface DEM in 1936 and 1990 can be produced using interpolated contours, while the surface DEM in 2009 can be produced using point GPS data, and the bedrock DEM was produced by subtracting the ice thickness data from the surface DEM in 2009. We note that the 2009 DEMs only partly cover the area of Pedersenbreen, as the coverage of GPS/GPR measured points is less than the whole glacier area. So the ice volume of the glacial tongue outside measured area (area A), the northwestern tributary (area B) and the steep uphill border (area C) needs to be estimated in another way. Limited to area A, surface and bedrock DEM (in 1936, 1990 and 2009) need to be reconstructed. For this reason, the GPS/GPR measured points on the left edge of area A, a portable GPS acquired points in the glacial tongue and contours in historical maps of Pedersenbreen are needed. Limited to areas B and C, we use its area in corresponding years multiplied by an average ice 
thickness to estimate its ice volume [16]. The average ice thickness of area $\mathrm{B}$ is given as $25 \mathrm{~m}$, where area $\mathrm{C}$ is given as $10 \mathrm{~m}$. Finally, the ice volume of Pedersenbreen is $V_{\mathrm{Y}}=$ $V_{\mathrm{G}}+V_{\mathrm{A}}+V_{\mathrm{B}}+V_{\mathrm{C}}$, here $\mathrm{Y} \in\{1936,1990,2009\}$. In the corresponding year $\mathrm{Y}, V_{\mathrm{G}}$ is the glacier volume limited to GPS surveyed area; $V_{\mathrm{A}}$ is the volume of glacial tongue without GPS measurement; $V_{\mathrm{B}}$ is the volume of the northwestern tributary; $V_{C}$ is the volume of unsurveyed uphill border area.

\section{Result and analysis}

\subsection{Ice thickness, surface and bedrock topography of Pedersenbreen}

Using the GPS data and GPR data acquired from field survey in 2009, we obtained the ice thickness map (Figure 3(a)), surface topography map (Figure 3(b)) and bedrock topography map (Figure 3(c)) of 2009. The thickest location of Pedersenbreen is $178 \mathrm{~m}$, while the mean ice thickness is $78.5 \mathrm{~m}$. Figure 3(a) shows that the closer to the central cirque, the larger the ice thickness. There is a theory that the ice thickness of one glacier may reach its top level near the snow line [25]. From this we can infer that the snow line of Pedersenbreen is at an elevation of $410 \mathrm{~m}$ from Figure 3. In the bedrock topography map, all the cross-sections are concave curves by taking them perpendicularly to the main- stream line. This is a typical characteristic of valley glaciers. Whether the cross-sections are U-shaped or V-shaped, which is relative to the evolution of this glacier [26], needs to be studied in future research.

\subsection{Changes in length, area, volume, average ice thickness of Pedersenbreen}

After getting the bedrock topography map of Pedersenbreen, we calculated area, volume and corresponding errors of Pedersenbreen in 1936, 1990 and 2009 (Table 2) using the methods described in section 1 . Then we analyzed the changes in length, area, volume and average ice thickness of Pedersenbreen during 1936-1990, 1990-2009 and 19362009 shown in Table 3.

The errors in calculating the area and volume of Pedersenbreen are mainly from two aspects. On the one hand, some original data is not accurate, especially the accuracy of the topographic map in 1936 is poor, and the correlation errors appeared in the correlating process. On the other hand, field GPS measurement failed to cover the whole glacier area, so the estimation of glacier volumes for areas A, B and $\mathrm{C}$ was inaccurate. This is also the main factor affecting the results of volume calculation. For conservative estimation, the maximum errors existed in glacier volume of areas A, B and $\mathrm{C}$ were $30 \%, 50 \%$ and $50 \%$ (the actual may be less),
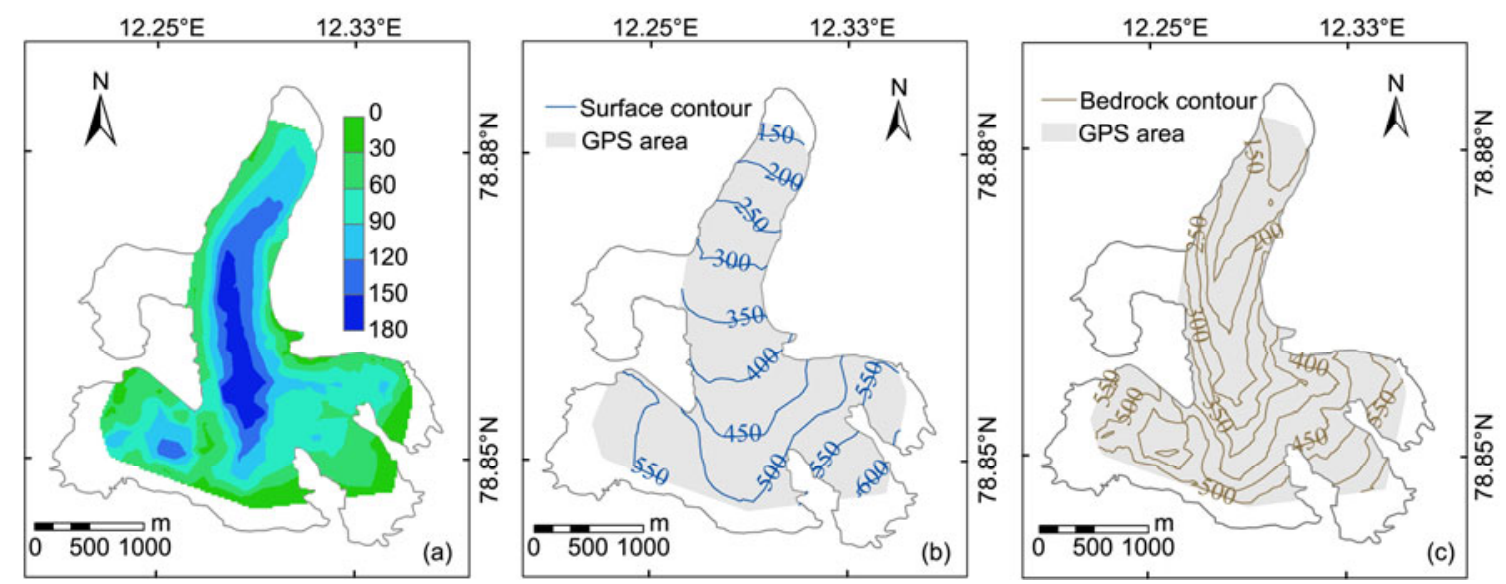

Figure 3 Ice-thickness map (a), surface topography map (b) and bedrock topography map (c) of Pedersenbreen in 2009. The glacier margin shown is that of 2009 .

Table 2 Glacier area and ice volume of Pedersenbreen in 1936, 1990 and 2009

\begin{tabular}{|c|c|c|c|c|c|c|}
\hline & \multicolumn{2}{|c|}{1936} & \multicolumn{2}{|c|}{1990} & \multicolumn{2}{|c|}{2009} \\
\hline & Area $\left(\mathrm{km}^{2}\right)$ & Volume $\left(\mathrm{km}^{3}\right)$ & Area $\left(\mathrm{km}^{2}\right)$ & Volume $\left(\mathrm{km}^{3}\right)$ & Area $\left(\mathrm{km}^{2}\right)$ & Volume $\left(\mathrm{km}^{3}\right)$ \\
\hline GPS area & 4.462 & 0.3820 & 4.462 & 0.3919 & 4.462 & 0.3504 \\
\hline Area A & 0.483 & 0.0316 & 0.224 & 0.0101 & 0.150 & 0.0061 \\
\hline Area B & 0.550 & 0.0138 & 0.620 & 0.0155 & 0.620 & 0.0155 \\
\hline Area C & 0.983 & 0.0100 & 1.104 & 0.0110 & 1.104 & 0.0110 \\
\hline $\begin{array}{l}\text { Sum } \\
\text { (error) }\end{array}$ & $\begin{array}{r}6.478 \\
( \pm 0.320)\end{array}$ & $\begin{array}{c}0.4374 \\
( \pm 0.0581)\end{array}$ & $\begin{array}{r}6.410 \\
( \pm 0.122)\end{array}$ & $\begin{array}{c}0.4285 \\
( \pm 0.0413)\end{array}$ & $\begin{array}{r}6.336 \\
( \pm 0.072)\end{array}$ & $\begin{array}{r}0.3830 \\
( \pm 0.0365)\end{array}$ \\
\hline
\end{tabular}


Table 3 Changes in length, area, average ice thickness and ice volume of Pedersenbreen during the periods 1936-1990, 1990-2009 and 1936-2009

\begin{tabular}{lccccc}
\hline & 1936 & 1990 & 2009 & $\begin{array}{c}\text { Change } \\
(1936-1990)\end{array}$ & $\begin{array}{c}\text { Change } \\
(1990-2009)\end{array}$ \\
\hline Length $(\mathrm{km})$ & 5.18 & 4.81 & 4.55 & -0.37 & -0.26 \\
Area $\left(\mathrm{km}^{2}\right)$ & 6.478 & 6.410 & 6.336 & -0.068 & -0.63 \\
Average ice thickness $(\mathrm{m})$ & 67.52 & 66.84 & 60.45 & -0.68 & -0.142 \\
Volume $\left(\mathrm{km}^{3}\right)$ & 0.4374 & 0.4285 & 0.3830 & -0.0089 & -6.39 \\
\hline
\end{tabular}

respectively. Considering the RMSE in ice thickness of $4.6 \mathrm{~m}$ in the surveyed area, the horizontal and elevation errors in original maps, all the errors calculated are shown in Table 2. Finally, except for the volume error in 1936 reaching $13 \%$, the rest of the errors are less than $10 \%$, which meets the needs of our research works.

Tables 2 and 3 show that the length and area of Pedersenbreen are declining continuously from 1936 to 1990 and 2009. Especially in the glacial tongue area, compared between 1936 and 2009, the terminal retreated more than 0.6 $\mathrm{km}$ in the past 73 years. The average ice thickness became thinner for $7.07 \mathrm{~m}$ and the volume reduced nearly $13 \%$. All these evidences show that Pedersenbreen has retreated since the end of the Little Ice Age (LIA). Compared between the period 1936-1990 and the period 1990-2009, we found that the averaged annual variations in the former 54 years were less than that in the latter 19 years. That is to say, Pedersenbreen has ablation in the most recent 19 years has been accelerating, which is consistent with the results from Midre Lovénbreen nearby [15].

During the period of 1936-1990, 1990-2009 and 19361990 , the volume of Pedersenbreen has decreased by 0.0089 , 0.0455 and $0.0544 \mathrm{~km}^{3}$, respectively, which is equivalent to averaged annual net mass balance value of $-0.023 \mathrm{~m}$ w.e. (water equivalent), $-0.338 \mathrm{~m}$ w.e. and $-0.105 \mathrm{~m}$ w.e., respectively, giving the ice density of $0.9 \mathrm{~g} / \mathrm{cm}^{3}$. It can be concluded that Pedersenbreen has been in a weak negative mass balance during the period of 1936-1990. However, Pedersenbreen has come to a dramatic negative mass bal- ance since 1990, which confirms the accelerating ablation trend in the recent two decades.

Studies have shown that the mass balances of Svalbard glaciers have presented a stable negative balance state from when observations started to the middle of 1980s. But in the late 1980s and early 1990s, the glaciers of this area had presented a balance state of zero or positive, reaching its maximum or most value. From then on the glaciers have been dropping to a stable negative balance state [27]. The net mass balance values of neighbouring glaciers have not exceeded $0.5 \mathrm{~m}$ w.e. at the same time by reviewing the observed balance values from Austre Brøggerbreen, Kongsvegen and Midtre Lovénbreen [28]. The resulting values of Pedersenbreen were in the same order of magnitude with the observed values, which supported our analysis of Pedersenbreen.

\subsection{Surface changes of Pedersenbreen}

The ice thickness changes of the glacier surface in the period of 1936-1990, 1990-2009 and 1936-1990 were analyzed by comparing the surface DEM in correlative periods, which are shown in Figure 4 with grid size of $1 \mathrm{~m} \times 1 \mathrm{~m}$. The northwestern tributary (area B) and the uphill border (area C) of Pedersenbreen were not considered in the analysis of surface changes for lack of data. The mean ice thickness of the two regions was supposed to be unchanged for the past 73 years when calculating the ice volume.

The downstream region of Pedersenbreen showed a

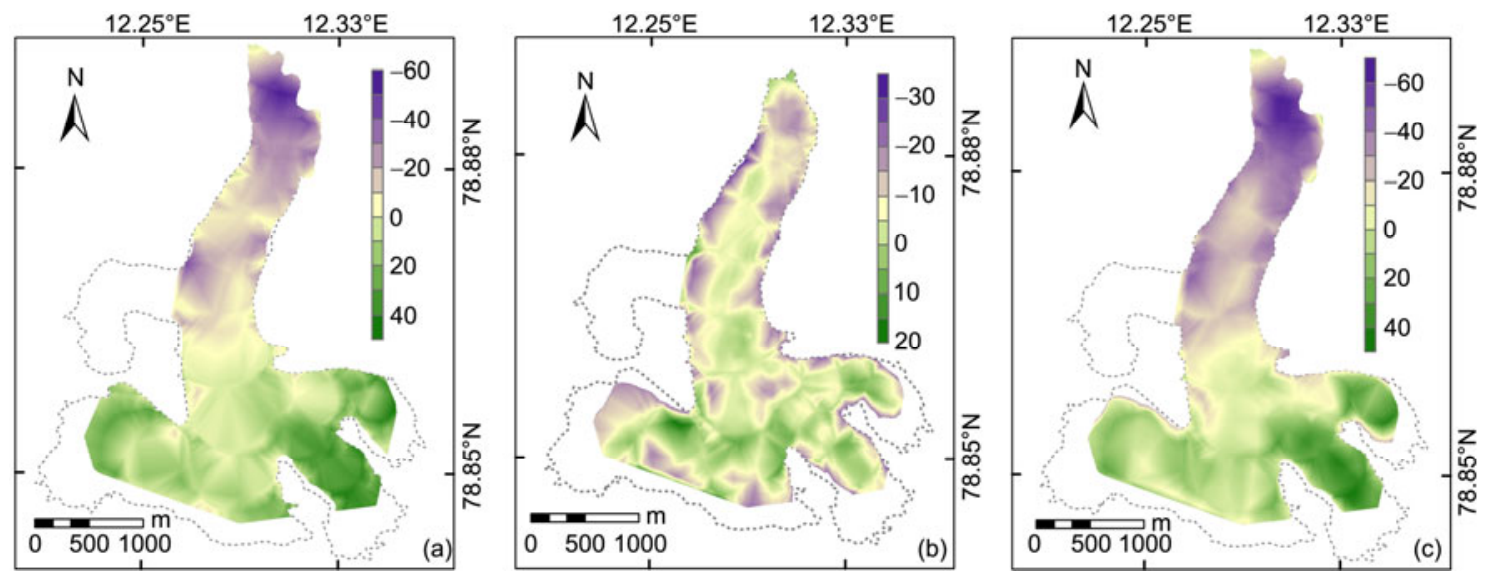

Figure 4 Ice-thickness changes of Pedersenbreen during 1936-1990 (a), 1990-2009 (b) and 1936-2009 (c). 
thinning trend in Figure 4. The ablation reached a maximum value of $60 \mathrm{~m}$ in the tongue area of 1990's morphology. On the upper accumulation zone of high elevation, ice was thickened, which was consistent with the changing trends of some other glaciers in Svalbard [24]. The accumulation zones and ablation zones, as well as the amount of accumulation and ablation of the corresponding years are counted in Table 4. Figure 4(a) and (c) shows a similar tendency and position of the ablation and accumulation zones on Pedersenbreen when the time span was over 50 years. Comparing Table 4 and Figure 4(b), Pedersenbreen was almost all in an ablation state during the period of 1990-2009, except a small accumulation area. Obviously Pedersenbreen has been in a recession since 1990, which also proved that Pedersenbreen is in an accelerated melting state in the recent two decades.

A significant number of glaciers in Svalbard are surgingtype glaciers. Some researchers believed that at least 30\%, even up to $60 \%$, of the glaciers in this area were surgingtype [29]. Pedersenbreen was also considered to have surged in history, but is in a quiet period now [18]. High-precision GPS measurements in recent years on glacier surfaces revealed a consistent characteristic pattern of surging-type glaciers in Svalbard [5,6]. One feature of a surging-type glacier in its quiet period is that the surface changes in the upstream and downstream areas present an opposing picture, which means that the retreat at the tongue area and the accumulation at the upstream result in the uplift of glacial elevation and speed up of ice-flow velocities [21]. The changes in surface of Pedersenbreen shown as Figure 4 were consistent with those surging-type glaciers in its quiet period. So far there is no systematic explanation on surging mechanism because glacier movement is related to dynamic mechanisms. The results in this study could not prove that Pedersenbreen is a surging-type glacier, but supplied one evidence supporting this deduction.

\subsection{The relationship with Pedersenbreen changes and climate}

The glacier change was caused by climate change. Its existence, growth and change of its scale depends on the climate change. For a special glacier, changes are mainly dominated by temperature and precipitation. As we have discussed before, Pedersenbreen has experienced a significant

Table 4 Accumulation and ablation area of Pedersenbreen for the three periods

\begin{tabular}{ccccccc}
\hline & \multicolumn{2}{c}{ Accumulation zone } & & \multicolumn{2}{c}{ Ablation zone } \\
\cline { 2 - 3 } \cline { 5 - 6 } & $\begin{array}{c}\text { Area } \\
\left(\mathrm{km}^{2}\right)\end{array}$ & $\begin{array}{c}\text { Amount } \\
\left(\mathrm{km}^{3}\right)\end{array}$ & & $\begin{array}{c}\text { Area } \\
\left(\mathrm{km}^{2}\right)\end{array}$ & $\begin{array}{c}\text { Amount } \\
\left(\mathrm{km}^{3}\right)\end{array}$ \\
\hline $1936-1990$ & 2.532 & 0.0358 & & 2.413 & 0.0458 \\
$1990-2009$ & 0.428 & 0.0014 & & 4.257 & 0.0469 \\
$1936-2009$ & 1.649 & 0.0215 & & 3.296 & 0.0771 \\
\hline
\end{tabular}

retreat after the end of the Little Ice Age, and is in a state of accelerated ablation in the recent two decades. These changing trends were consistent with the local climate change. Longyearbyen, which is about $100 \mathrm{~km}$ away from Pedersenbreen, has recorded an increase of more than $1^{\circ} \mathrm{C}$ of its annual averaged temperature in the past 100 years, and the increasing rate is $0.015^{\circ} \mathrm{C} / \mathrm{a}$ from 1912 to 2001 . Since 1976 , the temperature was apparently going up. The increasing rate of the temperature at Longyearbyen and $\mathrm{Ny}$ - Alesund is $0.078^{\circ} \mathrm{C} / \mathrm{a}$ and $0.042^{\circ} \mathrm{C} / \mathrm{a}$ respectively [30]. The increase in temperature will accelerate the melting of the glaciers. At the same time, annual precipitation in Svalbard has increased by $20 \%-30 \%$ in the past 80 years. The total annual precipitation increased in the past decades (since 1970) [31] and the summer precipitation was also increasing. But the snowfall in the winter was declining, which will lead to a decrease of ice accumulation in the winter and an increase of ice melting in the summer [32]. Considering the delay of glacier response to climate change, it may be 50-180 years according to Paterson's algorithm [33]. Therefore, if we keep present climate unchanged, the recession of Pedersenbreen will last to the end of this century or even to the next century. As global warming exacerbates, some researchers believed that the temperature in Svalbard would rise in the coming decades. It is estimated that the increasing rate of annual mean temperature from 1960 to 2050 will be four times that in the previous 90 years, achieving $0.061^{\circ} \mathrm{C} / \mathrm{a}$ [32], which will definitely speed up the melting of Pedersenbreen.

\section{Conclusion and discussion}

This study presented the area and volume of Pedersenbreen in different years, analyzed its surface change from 1936 using topographic maps and the field acquired GPS/GPR data. The following conclusions can be drawn from our analysis:

(1) Using the GPR data collected in 2009, we acquired the ice thickness map of Pedersenbreen in 2009 and found that the thickest location was in the central basin where the ice thickness is $178 \mathrm{~m}$. We also produced the surface topography map and bedrock topography map of Pedersenbreen in 2009 from the GPS data.

(2) The area and volume of Pedersenbreen in 1936, 1990 and 2009 were calculated from various data: the areas were $6.478,6.410$ and $6.336 \mathrm{~km}^{2}$, while the volumes were 0.4374 , 0.4285 and $0.383 \mathrm{~km}^{3}$, respectively. Both area and volume had a decreasing trend, meaning that Pedersenbreen has been in a recession since 1936.

(3) The recession of Pedersenbreen was remarkable around its tongue area. By 2009, the tongue terminal had cut back by more than $0.6 \mathrm{~km}$, and ice volume had decreased nearly by $13 \%$. Meanwhile the accelerated melting since the $1990 \mathrm{~s}$ was consistent with the change of many other glaciers under observation in Svalbard since the end of the Little Ice Age. 
(4) Pedersenbreen was mainly melting in the downstream of its tongue area, where there was thinning by more than $60 \mathrm{~m}$ at most. However, in the upstream area, some location had accumulated by more than $40 \mathrm{~m}$ at most. But in the recent two decades, the former accumulating area was shrinking greatly, which further proved that this glacier was in an increasing melting state.

(5) The glacier changes were caused by the local climate change. Both the increasing temperature and the increasing summer precipitation led to the accelerated melting of Pedersenbreen, and the glacier will suffer a greater recession in the coming years. In fact, we found that Pedersenbreen was almost in a totally negative balance from the monitoring stakes placed on the glacier [6].

Since the establishing of a monitoring system on Pedersenbreen in 2005, we have studied the glacier mass balance, glacier climate, glacier hydrology and surface ice-flow. This study belongs to the long-term monitoring works of Pedersenbreen. By analyzing its change in 73 years, adding some basic reference data of its area and volume, and producing some bedrock topography and ice thickness charts, we hope it will be beneficial to exploring the valley morphology, internal structure and the surge type of this glacier.

This work was supported by the National High Technology Research and Development Program of China (2012AA12A304), the National Natural Science Foundation of China (41076126, 41106163, 41174029 and 41176172), the Chinese Polar Scientific Strategy Project (20080203 and 20100103) and the Chinese Polar Environment Comprehensive Investigation \& Assessment Programmes (CHINARE2013-04-07 and CHINARE2013-02-04). We are very grateful to the anonymous reviewers who provided useful comments, which significantly improved the clarity and presentation of the results, and the Chinese Arctic and Antarctic Administration, State Oceanic Administration for sponsoring the field surveying and research works around Chinese Arctic Yellow River Station. Especial thanks to Roger W. Hagerup and Jack Kohler from Norwegian Polar Institute for their help finding the historical maps in this area. We also thank to Professor Bryan C. Storey from University of Canterbury and Bobby M. S. from Australian College Information Centre for polishing English of this paper.

1 Yan M, Ren J W, Zhang Z H, et al. The progress of glaciological studies in Svalbard and Chinese construction of glacier monitoring system close to Yellow River Station, Ny-Ålesund, Svalbard (in Chinese). Chin J Polar Res, 2006, 18: 137-147

2 Norwegian Polar Institute. Geological Map of Svalbard, Scale 1:100000 Sheet A7, Kongsfjorden. Norsk Polarinstitutt, Troms $\varnothing .2008$

3 Ren J W, Yan M. Glaciological investigation during the first scientific expedition of Chinese Arctic Yellow River Station (in Chinese), 2004. J Glaciol Geocryol, 2005, 27: 124-127

4 Ai S T, E D C, Yan M, et al. Arctic glacier movement monitoring with GPS method in 2005. Chin J Polar Sci, 2006, 17: 61-68

5 Xu M X, Yan M, Ren J W, et al. The studies of surface mass balance and ice flow on glaciers Austre Lovénbreen and Pedersenbreen, Svalbard, Arctic. Chin J Polar Sci, 2010, 21: 147-159

6 Ai S T, Wang Z M, E D C, et al. Surface movement research of Arctic glaciers using GPS method (in Chinese). Geom Inf Sci Wuhan Univ, 2012, 37: 1337-1340

7 Ai S T, Wang Z M, E D C, et al. Topographic survey on the surface of Austre Lovénbreen and Pedersenbreen in Svalbard based on GPS method (in Chinese). Chin J Polar Res, 2012, 24: 53-59

8 Shi Y F, Liu S Y. Estimation on the response of glaciers in China to the global warming in the 21st century. Chin Sci Bull, 2000, 45: 668-672

9 Li K M, Li Z Q, Gao W Y, et al. Recent glacial retreat and its effect on water resources in eastern Xinjiang. Chin Sci Bull, 2011, 56: 3596-3604

10 Li X Y, Ding Y J, Ye B S, et al. Changes in physical features of Glacier No. 1 of the Tianshan Mountains in response to climate change. Chin Sci Bull, 2011, 56: 2820-2827

11 Werner A. Holocene moraine chronology, Spitsbergen, Svalbard: Lichenometric evidence for multiple Neoglacial advances in the Arctic. The Holocene, 1993, 3: 128-137

12 Bamber J, Krabill W, Raper V, et al. Anomalous recent growth of part of a large Arctic ice cap: Austfonna, Svalbard. Geophys Res Lett, 2004, 31: L12402

13 Nuth C, Kohler J, Aas H F, et al. Glacier geometry and elevation changes on Svalbard (1936-90): A baseline dataset. Ann Glaciol, 2007, 46: 106-116

14 Hagen J O, Kohler J, Melvold K, et al. Glaciers in Svalbard: Mass balance, runoff and freshwater flux. Polar Res, 2003, 22: 145-159

15 Kohler J, James T D, Murray T, et al. Acceleration in thinning rate on western Svalbard glaciers. Geophys Res Lett, 2007, 34: L18502

16 Hagen J O, Liestøl O, Roalnd E, et al. Glacier atlas of Svalbard and Jan Mayen. Oslo: Norsk Polarinstitutt Meddelelser, 1993. 1-76

17 Hagen J O, Sætrang A. Radio-echo soundings of sub-polar glaciers with low frequency radar. Polar Res, 1991, 9: 99-107

18 Bennett M R, Huddart D, Hambrey M J, et al. Moraine development at the high-Arctic valley glacier Pedersenbreen, Svalbard. Geogr Ann A, 1996, 78: 209-222

19 Norwegian Polar Institute. Geological Map of Svalbard, Scale 1:100000 Sheet A7, Kongsfjorden. Norsk Polarinstitutt, Troms $\varnothing .1990$

20 Li X L, Zhu Q. Digital Elevation Model (in Chinese). 2nd ed. Wuhan: Wuhan University Press, 2003

21 Xie Z C, Liu C H. The Introduction to Glaciology (in Chinese). Shanghai: Shanghai Popular Science Press, 2010. 85-300

22 Seddik H, Greve R, Sugiyama S, et al. Numerical simulation of the evolution of glacial valley cross sections. arXiv: 0901.1177 [physics. geo-ph], 2009

23 Harbor J M. Numerical modeling of the development of U-shaped valleys by glacial erosion. Geol Soc Am Bull, 1992, 104: 1364-1375

24 Navarro F J, Glazovsky A F, Macheret Y Y, et al. Ice-volume changes (1936-1990) and structure of Aldegondabreen, Spitsbergen. Ann Glaciol, 2005, 42: 158-162

25 Zhang Y S, Zhu G C, Qian S L, et al. Radar measuring ice thickness of No. 1 glacier at the source of Urumqi River, Tianshan (in Chinese). J Glaciol Geocryol, 1985, 7: 153-162

26 Li Y K, Liu G N, Cui Z J. Glacial valley cross-profile morphology, Tian Shan Mountains, China. Geomorphology, 2001, 38: 153-166

27 Xu M X, Yan M, Kang J C, et al. Comparative studies of the glacier mass-balances and their climatic implications in Svalbard, Scandinavia and Southern Norway (in Chinese). J Glaciol Geocryol, 2010, 32 : 642-648

28 Johansson M. Mass balance data from Arctic Glaciers 2002. Abisko Scientific Research Station, 2002

29 Ingólfsson O. Outline of the geography and geology of Svalbard. University of Iceland and UNIS, 2004

30 Førland E J, Hanssen-Bauer I. Past and future climate variations in the Norwegian Arctic: Overview and novel analyses. Polar Res, 2003, 22: $113-124$

31 Førland E J, Hanssen-Bauer I. Increased precipitation in the Norwegian Arctic: True or false? Clim Change, 2000, 46: 485-509

32 Hanssen-Bauer I. Temperature and precipitation in Svalbard 19122050: Measurements and scenarios. Polar Rec, 2002, 38: 225-232

33 Cuffey K, Paterson W S B. The Physics of Glaciers. 4th ed. Amsterdam: Elsevier, 2010. 453-511

Open Access This article is distributed under the terms of the Creative Commons Attribution License which permits any use, distribution, and reproduction in any medium, provided the original author(s) and source are credited. 